University of Nebraska - Lincoln

DigitalCommons@University of Nebraska - Lincoln

Journal for the Advancement of Developing

Economies

Economics Department

2015

Cell Phone Repairers in Cameroon, 2000-2013

Walter Gam Nkwi

University of Buea, Cameroon, nkwi.walters@ubuea.cm

Follow this and additional works at: https://digitalcommons.unl.edu/jade

Part of the Econometrics Commons, Growth and Development Commons, International Economics Commons, Political Economy Commons, Public Economics Commons, and the Regional Economics Commons

Nkwi, Walter Gam, "Cell Phone Repairers in Cameroon, 2000-2013" (2015). Journal for the Advancement of Developing Economies. 30.

https://digitalcommons.unl.edu/jade/30

This Article is brought to you for free and open access by the Economics Department at DigitalCommons@University of Nebraska - Lincoln. It has been accepted for inclusion in Journal for the Advancement of Developing Economies by an authorized administrator of DigitalCommons@University of Nebraska - Lincoln. 


\title{
Cell Phone Repairers in Cameroon, 2000-2013
}

\author{
Walter Gam Nkwi \\ University of Buea, Cameroon
}

\begin{abstract}
This article focuses on cell phone repairers in Cameroon history. It examines how the cell phone has been appropriated by Cameroonians by repairing and extending its life. It questions the ways the repairers have understood the inner parts of the cell phones. How has the repairing of cell phones led to sustaining the livelihood of the repairers? It appears that life would have been unimaginable in the second half of the 21 st century without better communication. In Africa mobile phone communication has expanded exponentially over the last decade and will hopefully continue to do so during the coming decades. Cell phones have become an absolute necessity but behind and inside this gadget lay a complex world that is mostly out of sight. Using mostly interviews with the people implicated in the process, this paper contends that technology comes with its own creativity and youths are always the firebrands to understand and use it more than any other age group.
\end{abstract}

\section{INTRODUCTION}

According to Edgerton (2006: 13), "the story of the poor world which is a term referring to the euphemistic developing world ... which includes Africa and most of Asia, technology is usually told as one of transfer, resistance, incompetence, lack of maintenance and enforced dependence on rich world technology." This article draws on Edgerton's notion of creole technologies in Africa which are technologies transplanted from their place of origin, finding uses on a greater scale elsewhere. Edgerton notes that when things get older in Europe and America they tend to move to Africa, Asia and Latin America and when they moved into these areas, they come into contact with repair shops consequently. Maintenance might mean changing Creole technologies in all sorts of ways thereby giving it new lease of life.

In this article, I will use the notion of appropriation. Historians, anthropologists, and sociologists have used this concept to mean a situation whereby the technological object is removed from its professional location and is re-interpreted, adapted or even re-invented by those who are out of the vicinity of its original production (Appadurai, 1996; Castells, 1996; Manuel, 1990 and Akrich, 1992). Therefore, appropriating the cell phone technology in the Cameroon context is understood as something which is in sharp contrast from appropriating cell phones in the original homeland in which these phones were manufactured. It can be understood in two ways. In one context, appropriation could be understood as consumption and in this case, it will mean purchasing the object, recharging it and making calls with it. But in the other context in which it is used in this article, appropriation of the cell phone is actually about the mastery in a technical sense, in terms of the mastery of materials and technology. It is about repairing the cell phone. It is about extending the life of the cell phones and recreating new values. It is about re-production, skills and labor involved in the materiality of the cell phone (Beck, 2009). The technological appropriation of the cell phones can however be considered as another important instance of African agency and African 
creativity taking Cameroon as a case study in dealing with global goods. The study of how imported goods are invested with new local meanings, ways and methods of resurrecting the new technological object by the repairers is at the heart of this study. This article upholds the view that there is an interior world of materiality and practice to be discovered beyond the surface of the cell phone.

The growth of cell phones has been exponential. The International Telecommunication Union(ITU) revealed startling statistics over the growth of cell phones in Africa. From 51.4 million in 2003, the number of subscribers grew to 2,645 million in 2007 and 3,375 million by the end of 2008. This was seven times the growth seen in fixed telephone lines. The number of phones grew from 4.19 per 100 people in 2002 to 27.5 in 2007 and 32 in 2008. This shows that 77 percent was recorded between 2005 and 2006 while 40 percent on average over the period 2005-2008 (Cheneau-Loquay, 2010). Since 2005, the number of mobile phones has far exceeded the number of fixed line phones in all countries while area coverage is around 80-90 percent in urban areas in most countries and around 40 percent on average in rural areas. The cell phone has become a tool that is especially suited to the needs of a continent in which social life is intense and based on oral communication (Cheneau-Loquay, 2010). By 2014 the number of subscribers were estimated to have reached 2.3 billion (Sanou, 2014).

The expectations of its developmental potential at the level of the everyday life, as well as research endeavors, continues to be high (North et al, 2014; Sanou, 2014). In Africa, in particular, the rapid pace of adoption has garnered particular attention from scholars (Suominen, 2014; Carbonell, 2013; Nkwi, 2015; Nkwi, 2014e; Mbugua, 2014; Mbuagbaw et.al. 2013). Researchers looking beyond adoption reveal adaptive uses in rural and urban situations occasioned by men and women. For instance, in Burkina Faso, Hahn \& Kibora (2008) have carried out research in that direction. Further readings also suggest that such creative appropriations perhaps started with small business people. In urban Rwanda, as (Mehrotra \& Nguyen, 2012) have noted, the situation has not been different as both men and women have adopted the use of the mobile phone in a myriad of ways. Despite this plethora of research, there are still gaps exposed in the literature. This article attempts to fill such gaps using phone repairers in Cameroon as a category responsible for prolonging the life of this technological object and also sustaining their life through the repairing process.

Drawing from Beck (2009), this article argues that below the covers of telephones, there is a continuation of re-structuring and repairing which all fits into the interior world of technology and creativity embedded in the skills of the African youths which is still largely unaccounted for in Cameroon or little explored in the world of cell phone scholarship in Africa. In another study cited by George Klute (2009: 23), Beck (2001: 66-77) demonstrates that the introduction of technical innovations has to be understood as a dialectical process of appropriation in which both the external technical artifact and the society importing it undergo changes. These arguments have inspired me in this article in which I take Cameroon as a case study. The focus is to show how cell phone repair played an important role in the recycling or reviving of cell phones. What does it mean to repair the phone or to be a phone repairer? Given the time which the cell phone was introduced to Africa and the number of repairers so far, it is amazing how a technological artifact manufactured far away can be understood and repaired in another part of the globe. The telephone has become indispensable. It is so much a part of everyday life and culture that it has been totally "domesticated" (De Bruijn, et al. 2009). Clearly, the mobile phone is more than merely a means of calling or sending messages, 
photos, music, and phone numbers. For it to remain relevant, domestication is carried out through maintenance or repairs by people whose ingenuity have just developed around the object.

Edgerton (2006) notes that as things get older, they tend to move from rich countries to poor ones, from low-maintenance to high-maintenance environments. Many African, South Asian, and Latin American countries used vehicles imported from North America, Western Europe and Japan and lived almost eternally because they are in constant contact with numerous repair shops. Maintenance does not simply mean keeping those vehicles as they were; it may mean changing them in all sorts of ways - new gaskets made from old rubber, or new fuses made from scrap copper wire. Much of the world's mechanical ingenuity is devoted to creating robust, reliable, and highly adapted "creole" technologies, an ingenuity that is largely invisible to us only because we happen to live in a low-maintenance, high-disposal regime. Although not writing from the perspective of motor repairs, the ideas of Edgerton might as well hold true of cell phone repairs in Cameroon. The repairers are charged with the responsibility to resurrect or heal them in their shops using all sorts of spare parts just like patients are cured in a hospital. A cell phone repair shop is even known as "Mobile Phone Hospital" in Buea, capital of the southwest region of Cameroon.

I will start by sketching the history of telephone communication in Cameroon up until when the mobile phone was introduced. I will then show the methodology which was used to gather the data. The last part of the article will illustrate the biographical sketches of some of the repairers, as well as the tools they use to maintain the phones and why the phone repairs are important.

\section{A SHORT HISTORY OF TELEPHONE COMMUNICATION IN CAMEROON}

The history of telephone communication in Cameroon is intrinsically linked to its historical developments. Cameroon gained independence in 1960. Cameroonians continued using the land lines left by the colonial administration. In 1980, African economies, including Cameroon, started ailing. As a result, the Cameroon currency (CFA Franc) was devalued; the salaries of the civil servants were slashed three times. This was at the behest of the International Monetary Fund (IMF) with its Structural Adjustment Program (SAP) and it was meant to act as a palliative to the ailing economy. This affected the telecommunication companies as well. Some of the telecommunication companies were privatized. In 1998 the Cameroon Telecommunication Company (Camtel) was established by amalgamating Intelcom and the Department of Telecommunications at the Ministry of Post and Communications. The Cameroon Telecommunications Mobile Company (Camtel Mobile) was set up with the specific task of installing and exploiting mobile phones across the country. During this period of land lines, repairers were specialists trained in school of Post and Telecommunications. When the MTN and Orange companies were charged with the introduction of cell phones, a new set of repairers were born. This time not from any formal training but by mastering the technological environment.

However, studies on cell phones in Cameroon are generally scarce. Nkwi (2009: 50-68) traced the history of the telephone in Buea, a university town from the colonial period. It was the privileged few that used it to introduce cell phones when all have access to it. In my other article, I show how the use of cell phones by migrants from the Bamenda Grassfields of Northwest Cameroon in regions with a large diaspora have negated borders (Nkwi, 2014e). I had also extended the research to demonstrate the link between gender, sustainable development, and mobile phone culture in 
Cameroon (Nkwi, 2014f). Tabuwe et al (2013) examines the gender roles in Cameroon pink-collar ICT work. De Bruijn (2009) links cell phones to the history of migration and mobility in the Bamenda Grassfields of Cameroon. These few studies by any standard show the paucity of studies on cell phones in Cameroon.

A careful observation of cell phone use in Cameroon suggests that labor has not played a small role to keep the industry moving. Unfortunately, this has not yet caught the attention of scholars and researchers who have done some research on the subject of cell phones. Just like any technological object, the cell phone needs to be repaired so that it could be put into use again. This article contributes to the existing literature by showing how phones are repaired in Cameroon taking cognizant of the repairers. Various phone trademarks have found their way into Africa from many countries in Europe and more recently from Asia, especially China. These trademarks included Motorola, LG, Nokia, Samsung, HTC, Techno, and Itel. Various methods were used to gather data for this article.

\section{METHODOLOGY}

Two methods were used to gather data for this article - interviews and observation. I carried out unstructured interviews with people implicated in the process to get firsthand information about the subject matter and, by extension, their life histories. These interviews were held several times as need arose. I also spent hours at their workshops observing how they were working and the number of people that visited them with phone-related problems. After establishing a working relationship with them I followed some of them to their homes. The aim was to see whether their output was commensurate with the standard of living. The interviews used in this paper were conducted between 2000 and 2013 in most Cameroonian cities but more attention was paid to Bamenda and Buea all found in the Anglophone region of Cameroon. In the Francophone section of Cameroon, I concentrated in Douala which is the economic hub of Cameroon. Table 1 shows the total number of repairers whom I surveyed and interviewed during the research.

A cursory observation of the table above suggests that in the core urban areas of Douala, Bamenda and Buea, there are many more repairers than in other regions. These areas are dominated by administration and commercial activities. Users of mobile phones tend to be high as elsewhere in the world; business people, trendy younger people, managers, office workers are all in need of keeping their phones maintained. When cell phones were just introduced around 2000 they were meant for the privileged few who were able to afford it. As time went on, and cheaper Chinese phones entered the market, many other people such as street artisans, traders, and rural farmers saw the need to purchase them. The cheaper the phones the more its affordability and the more repairers cropped up to maintain them. Table 1 shows that the total number of repairers in the three regions was 226 in 17 locations.

This number can be further broken down into various categories of their social and educational backgrounds. Out of that number there were six university graduates with a first degree in ether physics, chemistry, or mathematics ranging from 19 to 28 years. One hundred and ten had a General Certificate of Education (GCE) Ordinary Level but in the science subjects (mathematics, physics, chemistry, biology, computer science) and ranged from 16 to 33 years. Ten didn't complete high school and had a GCE Advanced Level in science subjects whose ages ranged from 19 to 21 years. 
Table 1: Demography of Informants

\begin{tabular}{|l|l|l|}
\hline Region & Sub-Cities & Number of Repairers \\
\hline Southwest Region & Buea & 28 \\
\hline & Limbe & 14 \\
\hline & Tiko & 10 \\
\hline & Kumba & 11 \\
\hline & Mamfe & 3 \\
\hline & Mudemba & 2 \\
\hline Northwest Region & Bamenda & 29 \\
\hline & Fundong & 4 \\
\hline & Wum & 2 \\
\hline & Bali & 2 \\
\hline & Mbengwi & 1 \\
\hline Littoral Region & Douala & 68 \\
\hline & Nkongsamba & 24 \\
\hline & Yabassi & 12 \\
\hline & Edea & 8 \\
\hline & Kribi & 6 \\
\hline Total & $\mathbf{1 7}$ & $\mathbf{2 2 6}$ \\
\hline
\end{tabular}

SOURCE: Field notes of the author

The remaining ten were people who were secondary school dropouts and had come into the trade as apprentices. Their ages varied from 15 to 25 years. The gender dimension was striking. There were no women in the world of phone repairers. This could simply be because of the societal mentality which believes that such work is meant for men. But further looking at changes in the society where women now are becoming taxi drivers, motor bike riders, and builders, there is a likelihood that in the coming years women will enter the trade of phone repairs.

While in the field I followed the repairers and their working experiences that together formed the social dynamic described in this article. The informants cited in this article were a representation of the sum total of repairers. This article therefore depicts not only individuals but also a social process and the dynamics of a society. The individual repairers, however, matters. Their individual stories are significant but only when linked to the process and how they came to understand and perceive phone repairing in their own society. Below is a biographical sketch of one of the phone repairers which will help to buttress the argument which I am making here.

\section{FINDINGS AND DISCUSSION}

In this section, I show the repairers' backgrounds and how it affected their output. The section also examines how the repairing of cell phones have led them to sustain their livelihoods, as well as why they even took up the job. The section starts with Appolinaire Tellen who is one of the post university repairers. Apollinaire was born in 1981. He did his secondary education in Bishop Rogan Minor Seminary, Small Soppo, Buea. After that he enrolled in the University of Buea. He graduated with a B.Sc. degree in accounting. After that he went to Limbe, a few kilometers from Buea where 
he worked briefly with a Chinese fishing company. It was after working with the Chinese firm that he embarked on phone repairs, first as an apprentice and then getting his own repairing shop.

He owns a repairing shop where he repairs phones of all types. The shop also has spare parts which he sells to other phone repairers. The shop is made up of metal material about 2.5 meters tall and 3 meters square. It is roofed with zinc. The inner part of the shop is partitioned into two - where customers sit and where he does phone repairs with the many tools which he uses to repair his numerous phones. He has two bags full of old redundant phones. He uses only some spare parts of these phones to repair new ones. This is separated by half plywood and a wire net which he can easily see his customers and converse with them about their problems with regards to their phones. He has been repairing phones for the past ten years or so.

He starts his story in the following words:

"I went to Bishop Rogan and towards the end of my studies, I read physics, chemistry, and mathematics. Out of all these subjects the one that had a very positive impact and direct relations to phone repairs on me is physics. Both the cell phone and other stuff are built on electronics and electronics is built from physics. With physics now, my knowledge to read and write, plot and draw diagrams and download things is perfect. Initially, I did not only start with phone repairs but rather with desktop operation. This computer maintenance has the skill like that of cell phone. It also takes the same tools to repair as with that of the cell phone. Original phones are the exceptions because they almost all the times catch virus. This is because they have an operational system. These operational systems are the same ones that you will find in computers and desktops. Apart from phone repairs, I repair laptops, digital cameras, computers, desktops, coils, and even fans, etc. I came to repair phones in a very interesting way but out of frustration. I learnt from friends and the internet. That was in Limbe, precisely at Free Market. I started as an apprentice to one Ghanaian whose names I only knew as Dickson. He has hardly gone beyond the elementary school (I wonder whether he even completed the elementary school), but he was a good phone repairer. The more I did more research the more I knew better than my master. This was because I had an additional advantage in that I had been to secondary and high school and unto a university and knew how these phones functioned in theory and practice. My dream after the university was to specialize in chattered accountancy... somewhere in Europe but my father ran out of business. One day the man just told me that I should look for another place. This was a polite way of dismissing me and so my life and phone repairs took another turn. I needed to work for my daily bread (clothing, feeding and catering for rents and hospital bills) rather than depending on my parents all the time. So, I searched and got this workshop..." (Appollinaire Tellen, personal communication, 23 April 2013).

Appollinaire represents those who have reached the university level and read accountancy at the first degree. His story reveals to us certain issues that cannot be overlooked in the phone repairing industry. His master had hardly been to a secondary school and there are doubts whether he even completed elementary school. This shows the place of talent encapsulated in creativity. One must not necessarily go to secondary school before qualifying to repair phones. Appollinaire's entering the phone repairing industry suggests that it was not his initial vocation. He had been to Bishop Rogan Minor Seminary whose main aim is to train Roman Catholic priests but after his General 
Certificate Ordinary Level he quit. Again, his initial dream after the university was to be a chartered accountant, but his father, who was his sponsor, ran out of financial support. For him to make the best out of the worst situation and meet his daily necessities, he embarked on phone repairs. An observation carried out in his shop shows that he attends to at least 25 phones per day. The money he gets from these repairs helps him to pay his hospital bills, pay his rent, feed himself, and at least put on clothes.

Those who had obtained the General Certificate Examination at the ordinary level were the most out of all the repairers. This category had the misfortune of not continuing their education to a higher level either. Julius was one of them. After his General Certificate of Education Ordinary Level, he met his frustrations. His father had a stroke and died because he had gone on retirement and his pension benefits had not been paid. According to him phone repairers was, to him, the last resort. As Emmanuel puts it, "It was never my dream to become a phone repairer one day. Today I still dream to go back to school". Emmanuel faced a similar situation with his uncle who had been responsible for his education since he started elementary school because of the death of Emmanuel's father. They explained that they did not go into the repairing of cell phones because they loved but rather, they realized that repairing cell phones could give them quick cash which they can use for their daily necessities. Others testified that while they repair the phones, they still had an ambition to go back to secondary schools, complete and go further to the university levels. This view was also shared by those who had attempted to reach high school and dropped out. Financial difficulties appear to have been the main factor which was responsible for their dreams to alter. The financial quagmire faced by these youths cannot be extrapolated from the socio- economic difficulties which the countries of Sub-Saharan Africa and Cameroon in particular have been facing since the mid1980s.

One of the countries which youths have displayed a high sense of agency and creativity in Africa within the period of economic blizzard has been Cameroon. The economic crisis began in the mid1980 s and affected the country right into the 21 st century. The general census, which was published in 2010, showed that 43.6 percent were younger than 15 and 47 percent fell within the ages of 19 and 35. In Douala, the economic capital of Cameroon, 22 percent of young people are officially unemployed. The youths mostly work in the informal sector in jobs ranging from motorcycle taxi drivers or as "call box" owners who offer telephone calls on the streets in return for meager incomes. Underemployment among the youths with a higher education, which has reached 78.5 percent, is a source of great frustration to the youths.

The country's nepotism and corruption aggravated the malaise of young people and contribute to their loss of confidence in the state. The youths thrived on the assumption that it is impossible to gain entrance to a university or find a job without the support of a powerful sponsor or without bribery. Youths are aware that many of their peers with university degrees are unemployed while less qualified workers get jobs through nepotism. Access to professional schools is also dependent on "contacts"1 and "god fatherism" and many too cannot afford to enter the university because of the rising cost in the University cities.

As a result of disillusion, many believe that they could only get a job when they had a relation or a friend at the top who could influence their employment. Again, they felt so because the general

\footnotetext{
1 "Contacts" is a very generic term which got its roots especially from the youths.
} 
atmosphere of the country is that which relies on mediocrity than merit. Many in the provinces see Yaoundé, the administrative capital of Cameroon, as benefitting from the economic activity of their entrepreneurial city and see Yaoundé civil servants embezzling state funds while leaving them without roads and electricity. This is quite debatable as many in Yaoundé could be poorer than those in the provinces, living in slums that are dirtier than the villages.

With all these challenges, the government handling of the youth situation has been ambiguous. In 2004, following Decree No. 2004/320 of December 8, 2004, the government created a separate Ministry of Youth Affairs. Amongst other things the ministry had new structures such as the Department of Youth Economic Promotion and the Department of Citizen Education, Social Integration and Youth Participation. The new ministry was also given a professional orientation with the appointment of a seasoned Professional Youth and Sports Lecturer, Adoum Garoua (Ewumbue and Monono, 2009: 11-12).

Furthermore, during the president's traditional Youth Day message, on February 10, 2013, he mentioned the youths, especially those who were motorcycle taxi drivers. The consequence of such a statement pertaining to the youths received its desired effects. Less than one month when the speech was broadcasted (March 1,2013) approximately ten thousand commercial motor bike riders from across the country staged a support march in Yaoundé in Biya's acknowledgement of them (Mokake, 2013). "Since then various politicians have exploited this development to make political capital out of it in the guise of organizing the sector or through distribution of free helmets" (Mokake, 2013: 7). On the other hand, the government launched in 2012 a program, the National Civic Agency for Participation in Development, through which it sponsors business projects of youth groups in the entire country. The students have seen the government's efforts as a political gimmick and have not taken them seriously While caught at the "horns of dilemma" the youths were bound to become more creative and therefore had to navigate their ways in a more meaningful strategy or simply migrating to Europe, America, or China, when they must have been convinced and imagined that these places were lands of beer and skittles.

Furthermore, most of the informants in this article come from backgrounds which cannot sustain them. Their sponsors have been and are still rural farmers depending on subsistence agriculture for survival. Sometimes, the repairers are those who even helped their family members to send home some money as one of our informants Ignatius Ngenai said: "Through the repairs of these phones I gather some money and send it to my parents who pay their hospital bills as well as take care of my siblings in primary school" (Personal communication, June 23, 2012). Again, Cameroon is one of the countries in the world which have very little regard to workers when they are on retirement. Most retirees wait eternally for their pension benefits and most again finally die. This has produced many orphans who have to fend for themselves.

\section{TOOLS USED FOR REPAIRING CELL PHONES}

The tools which are used to repair phones vary and repairers use them as they see fit. Most of the repairers started with a soda iron. In a conversation with one of the repairers, John Ngenui, he said:

"When I graduated from the workshop, I had to start a new life with a workshop of mine, which meant that I was to acquire tools. The first and an important tool which I started my 
workshop was this soda iron (pointing at the tool). Normally the one I am supposed to use is 60 watts, but it is out of the market. This one was bought in Douala for 5,000 FRS CFA (EUROS 8). That was the least amount of money I could afford to start off this business since initially I was not surviving on an income from my master. Even going to Douala to purchase this tool was not easy. I did that all the way because of its importance to the entire business of repairing phones. It is used to re-soda and con-soda" (John Ngenui, Personal Communication, April 12, 2012).

The pen of a phone repairer is the multimeter. According to Francis Njei, a multimeter detects the nature of what has gone wrong with the phones when it first comes into the workshop. That is to determine the particular problem which is affecting the phone. It is also very important because you can easily know a problem which is affecting the phone without even using a soda iron. It also detects the circuits whether they are bad or good (Francis Njei, personal communication, May 10, 2013).

Another tool is the Lucky 902 or Power Station 902. It is used to remove printable ICs from the phones and sometimes the laptops. It is only in the presence of heat that these printables can be removed and the Power Station 902 has that advantage. It also has the power to detect temperature variation. This helps significantly because at times high temperatures could easily destroy some of these instruments. So, because of the Power Station 902 it could easily be known and detected at what temperature a particular instrument could be repaired. (Francis Njei, personal communication, June 13, 2013)

The laptop is another tool used by phone repairers. It's like the research page because it is used to access various websites and find out what has gone wrong with the cell phones. Through the laptop and internet, the repairer can decode and code phones. It's also though the desktop, with the use of internet, that repairers download software which is used to repair the phones. So, without the internet nothing actually works; to save time most of the repairers have decided to own a modem, otherwise they will always be at the cybercafé. According to Joseph Gang, to decode, repairers use what is known as a box. There are many boxes which have software. There is the Unity box, Tornado, and Spider-man. These boxes are sold online and can be very expensive. For instance, the box for blackberry is 500,000 FRS CFA $(€ 800)$. Some of the boxes are paid on a daily basis like the Ernestone box which repairers normally pay 40,000 FRS CFA (€ 61). Screw drivers are also used in the repairs of cell phones. These are used to open the small phones and they are of different sizes too. There is also the power supply which is obviously meant to provide electrical power for the devices. (Walter Ngubi, personal communication, August 14, 2013) Whether the repairers were from secondary school, post-secondary, or were university graduates, they confronted common challenges which called for them to form a union.

\section{THE UNION OF PHONE REPAIRERS}

The number of people in need of their phones to be repaired has been in an increase. So too are phones for sale in a rapid increase and the cheaper the phones are, the more they go bad and need the services of repairers. This has led to the evolution of the brotherhood or solidarity of repairers also known as the union of phone repairers. The evolution of a relatively broad community bound together by common practice suggests that it is one of the key explanations for their creativity. 
Beck (2009: 166) observes that "the very foundation on independent though connected local repairs workshop traditions of getting things done has served as a seedbed for an evenly broad process of differentiation and consolidation of innovations." The typology of the phones themselves appears to have served as the most efficient media for the dissemination of innovations by circulating through the Cameroon's network of repairers' workshops in search of maintenance and repair. By so doing they freely offer the materialized knowledge incorporated into their bodies to everybody able to make sense out of it. One of the repairers remarked that, "Today we can boast of repairing not less than twenty-five phones a day. Thanks to our union whose members share knowledge freely. The increase in the demand for phones to be repaired is what has led to us coming together for our collective interest and well-being" (Personal communication with Julius Nibem, May 21, 2013).

The history of the union goes back to 2010, when twenty-eight cell phone repairers in Buea, in the administrative headquarters of Southwest region of Cameroon, came together and formed a union and a forum which was meant to share ideas and challenges around the repairs of cell phones and the wellbeing of the repairers. This was championed by Alexander Echin, a secondary school dropout, who had learnt and studied mobile phone repairs in a "Mobile Phone Hospital" workshop. He explained that the purpose of forming this union was because the repairers had realized that they could not work isolated from each other. They needed the help of each other. They also operated a small Njangi, a creole word meaning loan and thrift scheme. Basically, this loan and thrift scheme was to help members to improve their living by being able to pay their house rents, foot their hospital bills, and pay the school fees of their children. To achieve that aim members had to save some money and could also take loans with reduced interest rates. It is well structured. At the top are the president of the union, the vice president, secretary, treasurer, and publicity secretary.

The repairers usually met every Sunday except if there was an emergency problem. These Sunday meetings were meant to share common challenges and difficulties encountered during the week in the repairing of phones. When somebody had encountered what the repairers usually called "a viper", the problem was brought to the forum. The viper is not a type of snake as we know but rather it is the crossbreed of or the consequence that occurs while the repairer is attempting to repair another problem. When this type of a thing happens, the person brings it to the special branch of the union known as the education forum. Another technician who had a sense of dealing with it helped out by explaining to his colleagues. The education forum brings together all the technicians irrespective of their intellectual abilities and qualifications. It is meant for technicians to educate each other on what they know may be more than their colleagues. It therefore helps repairers in sharing and cross-pollinating ideas.

A better scrutiny of the mobile phone repairers revealed something deeper which is linked to the cell phone. This is the social networks which have been generated by the object. Buying a phone and making it work puts a strain on budgets, and this has prompted some people to band together in order to buy phones and obtain better rates. At one of Khartoum's universities, students have set up a "tontine" scheme that allows members to set aside money and obtain the sum they need to buy a phone (Brinkman et al. 2009). In Burkina Faso, pools are formed by professionals to force the price down. The pool is based on the fact that in general, the communications network of economic agents is known. It may comprise actors involved in related activities (salespeople, for example), employees of the same ministry. The formation of the phone repairers' union in Cameroon may as 
well be pointing to an ongoing phenomenon in social networks which has been generated around the cell phone. Mobile telephony in Africa illustrates one fundamental feature of the way in which the new technologies are being used: innovation comes about as much as a result of user practices as in laboratories. The talk is of "innovation through use" which Dominique Cardon defines as "technological and service innovations that come about as a result of user practices and are disseminated through the exchange networks between users"(Cardon 2005:45). The approach adopted by Mde Certeau, (1984: 95) with subtle descriptions of users' "arts of doing" and "ways of doing", has shown how ordinary people demonstrate creative abilities to invent on an everyday basis, four of which manufacturers are unaware: they make resourceful use of makeshift solutions and short cuts in order to create a personal way into the world created by the manufacturers and to appropriate the technologies for their own use.

\section{CONCLUSIONS}

The introduction of a technological object into the society could have far reaching ramifications hitherto unknown. The cell phone so far has generated such unforeseen consequences. They have affected the human world in various creative ways. Fundamentally, in Africa, it has led to the rise of a class of people in their own right known as repairers. These are "technological wizards" who have mastered the internal world of the cell phone and can recycle it using various tools. The rise of repairers suggests further creative use of the cell phone which Africans can easily adopt it in their context. Using Cameroon as a case study, the repairers illustrate the fact that one does not necessarily need to be where a technological object is manufactured before he/she could master how to repair it. The backgrounds and life histories of the phone repairers lead us to the conclusion that phone recycling through the repairers creates meaningful employment to the youths. Most of them have entered the industry because of the economic downturn which affected the country in the 1980s. One can therefore also conclude that the economic malaise had a positive affect as many youths had to realize their talents because of the downturn. The paper further contends that the African agency in appropriation of technology, especially the mobile phone, needs to be paid more attention to in the academia. This article has started that journey.

\section{REFERENCES}

Akrich, M. (1992). The description of technical objects. In W.E. Bijker \& J.Law (Eds.), Shaping Technology/Building Society: Studies in Sociotechnical Change (pp. 205-240). Cambridge: MIT Press.

Appadurai, A. (Ed.). (1996). The Social Life of Things: Commodities in a Cultural Perspective. Cambridge: Cambridge University Press.

Beck, K. (2009). The art of truck modding on the Nile (Sudan): An attempt to trace creativity. In J. B. Gewald, S. Luning, \& K. van Walraven (Eds.), The Speed of Change: Motor Vehicles and People in Africa, 1890-2000 (pp. 151-174). Leiden: Brill.

Carbonell, X., Oberst, U., \& Beranuy, M. (2013). The Cell Phone in the Twenty-first Century: A risk for addiction or a necessary tool? In P.M.Miller (Ed.), Principles of Addiction (pp. 901909). San Diego: University of San Diego Press.

Castells, M. (1996). The Rise of Network Society. Malden, MA: Blackwell.

Certeau, M. (1984). The Practice of Everyday Life. Los Angeles: University of California. 
Chene-Loquay, A. (2010). Innovative ways of appropriating mobile telephony in Africa.

Republique Francaise: International Telecommunication Union.

De Bruijn, M., Brinkman, I. \& Nyamnjoh, F. B. (Eds). (2009). Mobile Phones: The New Talking Drums of Everyday Africa. Mankon, Bamenda and Leiden, The Netherlands: Langaa/

African Studies Centre

Edgerton, D. (2006). The Shock of the Old: Technology and Global History Since 1900. London: Profile Books.

Ewumbue-Monono, C. (2009). Youth and Nation Building in Cameroon: A Study of National Youth Day Messages and Leadership Discourse, (1949-2009). Mankon, Bamenda: Langaa RPCIG.

Hahn, H.P. \& Kibora, L. (2008). The Domestication of the Mobile Phone: Oral Society and New ICT in Burkina Faso. Journal of Modern African Studies, 46(1), 87-109.

Klute, G. (2009). Modern chariots: Speed and mobility in contemporary "small" wars in the Sahara. In J.

B. Gewald, S. Luning, \& K. van Walraven (Eds.), The Speed of Change: Motor Vehicles and People in Africa, 1890-2000 (pp. 191-211). Leiden: Brill.

Mehrotra, A. \& Nguyen, A. (2012). Differences in phone use between men and women: Quatitative evidence from Rwanda. In Proceedings of the Fifth International Conference on Information and Communication Technologies and Development (pp. 297-306). California: ACM.

Mbugua, S. (2014). Technology helps Africa's women farmers close the gap. Thomson Reuters Foundation.

Mbuagbaw, L.M., Kop, L. van der, Lester, R. T., Thirumurthy, H., Pop-Eleches, C. Smieja, Thabane, L. (2013). Mobile Phone text messages for improving adherence to antiretroviral therapy (ART): A protocol for an individual patient data meta-analysis of randomized trials. BMJ OPEN, 3,1-9.

Mokake, F. M. (2013). Youth and Currency Counterfieting at Crossroad with a Special Reference to Mutengene (Cham), Cameroon. Childhood in Africa: An Interdisciplinary Journal, 3(1), 116.

Nkwi, W. G. (2009). From the Elitist to the Commonality of voice communications: The History of the Telephone in Buea, Cameroon. In M. de Bruijn, I. Brinkman, \& F. B. Nyamnjoh (Eds.), Mobile Phones: The New Talking Drums of Everyday Africa (pp. 50-69). Mankon, Bamenda and Leiden, The Netherlands: Langaa/ African Studies Centre.

Nkwi, W. G. (2015). African Modernities and Mobilities: An Historical Ethnography of Kom, Cameroon, c. 1800-2008. Mankon, Bamenda: Langaa RPCIG.

Nkwi, W. G. (2014e). Gender, Sustainable Development and Mobile Phone Culture in Cameroon, c.2000-2010. Journal of Sustainable Development in Africa, 8(6), 44-60.

Nkwi, W. G. (2014f). Cell phones, Migration and the ambiguity of borders in Bamenda Western Grassfields (Cameroon). Analele Unversitati Bucaresti, No. 8: 21-34, Faculty of Business and Administration, University of Bucarest, Republic of Roumania.

North, D; Johnston, K., \& Ophoff, J. (2014). The Use of Mobile Phones by South African University Students. Issues in Informing Science and Information Technology, 2, 115-138.

Nyamnjoh, F. B. (2005). Africa's Media: Democracy and politics of belonging. London: Zed Press.

Pilaf, J. (2009). The Mobility of a Mobile Phone: Examining 'Swahiliness' through an object biography. 
Sanuo, R. (2014). ICT Facts and Figures. International Telecommunications Union Publication. Suominen, A., Hyrynsalmi S., \& Knuutila, T. (2014). Young mobile phone users: Radical and Individual. Telematics and Informatics, 31(2), 266-281.

Tabuwe, M. E., Muluh, H. Z., Enoh T., Akpan-Obong, P., Sikali, L., Ngongban, A., ... \& Wacham, V. (2013). Gendering Technologies Women in Cameroon Pink-Collar ICT Work. International Journal of Management and Information Systems. 17(1), 213-222. 